\title{
Southern Honor: An Analysis Using American Studies
}

\author{
Imam Basuki \\ Universitas Jember \\ (Imabas88@gmail.com)
}

\begin{abstract}
The goal of this article is to discuss Southern Honor, the work written by Brown using American Studies Approach/ theory. American Studies is an interdisciplinary discipline comprising of social science, humanities, history, art, economics, sociology, anthropology, politics, religion, and law. In American studies method, a researcher, for instance - from a discipline of historical science- in collecting data, he or she does not only use data from history but also from a literary work like novel or drama because a literary work was a mental fact of society at that time This makes American Studies different from the other disciplines. Southern Honor by Brown is an example of work written by American Studies approach using three principal theories of American Studies such as: 1 . Reconciliation of Tenses (Past, Present, Future); 2. Reconciliation of Academic discipline (Anthropology, Economy, Politics, Sociology, Psychology, Literature, and History); 3. Reconciliation of Region, Nation, and World. For the theory of number 3 starting from something micro namely "Honors" in the society of southern America like "gentle", "oath", possession of wealth, and so on can explain more detail about America. The result of this research proves that "Honor" does not only give influence on the ethic and behavior of southern American society at that time, before civil war, but also provide influence on all aspects of life of American society as a whole up to now.
\end{abstract}

Keywords: American Studies, Southern Honor

American Studies is one of academic disciplines which has an important role in the growth of American civilization. The role of American Studies not only concerns information about the United States but also as an academic discipline. The main object of American Studies is the American experience, so the presence of American Studies as an academic discipline brings fruitful methods to reveal the American experience.

Gene Wise (1975, p. 293) in his essay entitled Paradigm Dramas in American Studies: A Cultural and Institutional History of the Movement stated that for a movement so critical of the culture around it, American Studies recapitulates America in revealing ways. Both began as revolts against the established orderfor America, the Old World, for American Studies, the traditional discipline. In contesting the old, both have articulated visions of a new and better order.

Since the birth of American Studies in 1920s, there have been numerous issues on the existence of American Studies. One of the major issues was about the methods in American Studies which are different from other academic disciplines. The search for methods in American Studies had been carried out by Americanists. The first effort was pioneered by Vernon Louis Parrington who 
wrote a book entitled Main Currents in American thought (1927). In this work, Parrington proposed a method to be used in American Studies namely Intellectual History Synthesis.

The work of Parrington was then followed by other Americanists, such as Perry Miller, Henry Nash Smith, and Allan Trachtenberg, etc. They proposed certain methods which were appropriate in American Studies discipline. For example, Henry Nash Smith used a method of myth and symbol to explain his book, Virgin Land (1950), David Potter, in his book entitled People of Plenty (1954) proposed the use of various disciplines instead of history to explain the national character in America; Alan Trachtenberg, who wrote Brookly Bridge (1965), used fact and symbol method to show the significance of the Brooklyn Bridge in American society, etc. Thus, each of them tried to show the American experience.

One of the important points to be noted in relation to the American Studies discipline here is the aspects that differentiate the American Studies work from other works of academic disciplines. For this reason, is interesting to explore the application of American Studies theory in the literary writing in order to see the difference of American Studies and other academic disciplines. In this article, the discussion will be focused on the book Southern Honor (1982) written by Bertram Wyatt-Brown.

Based on the foregoing explanation, we can see that there were many approaches in American Studies theory. Since American Studies are concerned with the American experience, these approaches are, of course, intended to explain the American experiences. Southern Honor is one of the books written by using an American Studies approach. Before exploring the American approach used in the book Southern Honor, it is firstly, important to know the basic theories in American Studies.

There are three important cores in American Studies theory. Tremaine McDowell in his book American Studies (1948, p. 82) stated that American Studies move toward the reconciliation of the tenses, the reconciliation of the academic discipline, and third long range goal, namely a reconciliation of region nation, and world.

The above cores suggested that the work of American Studies will view the American experience from the past, present and future. The past experiences affected the present ones, and the present ones contribute to the future experiences. The reconciliation of various academic disciplines meant that the American experience will be viewed from various academic disciplines; that the American Studies will rely much on the use of interdisciplinary approach. The reconciliation of region, nation, and world proposed that the work of American Studies should be viewed from the micro to macro analysis.

Further, Merideth in his book American Studies (1968, p. v-vi) stated that where we wer to study American civilization past, present future; the acceptance of all three tenses was a major doctrine in American Studies. We wer to reconcile the three tenses by stressing their continuity in an open universe. We were also to reconcile the academic disciplines, and region, nation, and world to lay the foundation for the reintegration of man in the coming age of the modern. The aim was a synthesis of knowledge the broad outline of knowledge, relationship, patterns, enrichment, cross-fertilization an the obstacle to these was their opposite extreme ademic specialization.

By examining the above three cores in American Studies, we will be able to recognize one work, whether it is a work of American Studies or not. The book Southern Honor exemplifies the work of American Studies. By examining the whole book, it can be found that this book applies the theories of American Studies as explained above.

To be clearer in exploring the application of the American Studies approach in this book, it is important to first clarify the fundamental theoretical views that can be used. Of course, this will concern the American Studies theory. So, the discussion in this article will begin with the discussion on the American War (1800-1860). However, if the whole book Studies Approach, which becomes the basis in is examined carefully it can be found that the which the book is analyzed, and then move to explanation not only applies to that period, the analysis itself.

The discussion will be directed toward the research question as follows:

1. Why is the book Southern Honor called an American Studies work?

2. What theories of American Studies applied in Southern Honor?

\section{The Theories of American Studies Applied} in Southern Honor

As stated above, the book Southern Honor is one of the books written with in an American Studies approach. As a whole, this book talks about the life of the Southerners. It was stated that the Southerners had certain honors which made them different from the other people in America. These honors could be found in their family life, their gender behavior, their community, etc. Such honors as gentility, courage, etc. made them distinct from the other Americans.

Seeing the content of this book, it can be said that Southern Honor has important significance in American Studies. The exploration of the honors possessed by the Southerners as one part of American society is one characteristic of American Studies whose aim is to study American experience. Southern Honor provides one example of American experience, in this case, the experience of the American South.

The significance of the book in American Studies can be explored if the methods of explanation are clarified. For this reason, analysis will be divided into three parts as follows.

The Reconciliation of the Tenses

In Southern Honor, It is explained the ideas by concerning the time concept, i.e. past, present, and future. Looking at the title Southern Honor: Ethics and Behavior in the Old South, one may think that it is just explained the honor of the Southerners in the period of Old South, which is the era before the Civil but also before and after that period.

In dealing with this time context, it is stressed that the present honors of the Southerners are greatly influenced by the ethics and behavior of their ancestors from the Old

World, Europe. It was stated also that some of their present honors still persist in the period

For example, for the context of past times, it is stated that the honors of the Southerners has roots in their Western tradition. There are two ethical strands that coexist in Western culture that have relevance to the South. The first may be called Pagan or Indo-European Ethics; the second was Stoic Christians (p. 26). The honor derived from the Indo-European system of ethics will be called Primal Honor. From the Stoic-Christian system that the English humanist began to cultivate, there arose the concept that thereafte will be spoken of as gentility (p. 34). The Southerners undoubtedly possessed honors uch as the tension of Patriarchy, the tightness valor, blood, bonding as the Primal Honor nd also the gentility including sociability, earning, and piety. Another statement that proved the relation of the book Southern Honor to the past times is that the possession of myths, rituals, oaths, grave sites, artifacts, nd most especially word roots all indicat thought from antique to recent ages (p. 33). The Southerners regard these human perceptions as their honors in American society. Also, this is because of these human perceptions that the formulation of the Southern evaluations of conduct becomes apparent.

The book Southern Honor also concern its relation to the Future Times. It was stated that the present honors of the Southerners in the Old South could also be found in the period after the Civil War or New South. One of the examples is the strong bonding of the Southerners to their family names. This kind of the New South, after the Civil War. common fund of human perceptions that 
of honor is endured not only in the period this feature, the Southerners are honored before the Civil War (Old South) but also it is and regarded as gentle... gentlemen were still endured in the period after the Civil War convinced that good order required regularity (New South). Brown further stressed this time of Christian doctrine... (p. 101). In relation context, as late as 1940 this kind of adherence to to the anthropological study, this way of life family names and their evocations still endured is truly significant since religion itself is a part (p. 124). Another example is the Southerners's of the cultural life, which is one of the main relationship that was not confined to the planter- objects in anthropological study. yeoman connection. This tendency existed not nly in the period of the Old South but before and after that. Brown stressed this tendency, this requirement was greatest in the seventeenthto be important in the Old South even beyond the Civil War (p. 63).

All of the above examples prove that there has been the reconciliation of the tenses in the book. The honors of the Southerners explored take place in the past, present and future.

The Reconciliation of Academic Disciplines

The reconciliation of academic disciplines or the use of interdisciplinary approach can also be found in the book Southern Honor. In explaining the ideas, Brown, the writer of this book not only relies on the historical background but also on various academic disciplines, such as anthropology, economics, politics, sociology, psychology, and literature.

\section{Anthropology}

The study of anthropology in the book Southern Honor is clearly seen because the book itself is concerned with aspects of the cultural life of the Southerners. One of the major issues in anthropological study is the cultural life of people. The cultural life of the Southerners can be found in this book, namely in their daily life, either in the family or in society as a whole. Some aspects of their cultural life are their strong tie to religious faith, strong relationship to their family, and also the strong consciousness in learning habit. In their relation to family, the Southerners are so devoted to their family, either between father and children, or mother and children. The Southern mothers play the dominant role in the care of an infant. The family also takes pride in the father, and relates to him in an affectionate way, and provides emotional support for him even though the fathers sometimes devote little routine time to them. This kind of relation can be seen in the way the father takes care of their children, for example, Give little Molly a thousand kisses for me, wrote George Braxton, a Virginia planter to his wife. Another one is, Remember me to the children and tell em I will be mad if they are naughty, declared Levin Joynes affectionalety in 1788 (p. 134). Such relationships have become part of cultural life of the Southerners.

While in learning habit, it seems that the Southerners has also great consciousnes in education. Indeed, it also has become part of their cultural life in the family and also in society. It is stated that the Southern ideal of education was necessary to equip young men for the world. That is why, learning marked the possessor as a gentlemen (p. 92-94).

Economy

Talking about economy, people will associate it with the ways they satisfy their daily needs; either in family or in society. Such a study is also found in the book Southern Honor. In other words, the possession of honors by the

One of the honots of the Southerners relating to their economic needs is their belief to aristocracy. It is known that the life of the Southerners in the Old South is dominated by the plantation system which then results in in family or in society, they always try to century American colonies, but it continued

The Southerners are said to have a

the concept of aristocracy. This way of life is determine their political roles in society. For based on their needs to fulfill their economic example, the Southerners regard the oath needs; that the Southerners will be honored taking as one of their honors in society. This much if they become aristocrats. That is why cultural life contributes much to their politica

they struggle to posses land as much as possible life. In political life, too, the oath often has a

The study of politics deals with the since the land possession becomes one way to be an aristocrat.

This way of life determines their honor in society. Brown further asserted that family honor requires the maintenance of wealth and, to a large degree, perpetuation of the planting occupation (p. 198). Moreover, the economic side of family life is conspicuously revealed in the plantation correspondence and personal diaries preserved in Southern repositories (p. 212).

In addition, the Southerner's strong tie to their blood kinship in marriage is regarded as one of the ways to get financial stability. Blood kinship through marriage offered the promise of stability, both financial and psychological (p. 222).

Moreover, the economic aspect can become the source for the formation of character, popularity, and power. Stewart, a Southerner from Arkansas said "what is it that constitutes character, popularity, and power in the United States? Sir, it is property; strip a man of his property in this country, and he is $s$ ruined man indeed; and he may have been raised in the highest circles of society (p. 74)". Also, possessions were regarded as an essential component of personality, family identity, and moral position (p. 72)

These facts prove that the honor of the Southerners is concerned with economy. Indeed, the economic power becomes the essential ways of life in the American South.

Politics ways of the people in maintaining their lives by preserving and conducting their human right in society; how they get involved in the decision making in society based on their right, etc.

Such a study can also be seen in rucial role to play.... Oaths among gentleme also figured in political activities (p. 57).

It is also found that the strong tie of the Southerners to their family indeed contributes so to their duty to the country: Loyalty to the family was transformed into duty to the country (p. 59) Furthermore, it was stated hat the characteristics of the Southern hono which relied much on the possession of the wealth, influenced their political hierarchy in society and related much to their power in overnment. The second element of honor in the Southern scheme of social and political hierarchy was the relationship of wealth to claims on government (p. 70)

From the above statements, it can be inferred that the honors possessed by the Southerners are also viewed from the political aspect.

Sociology

The study of sociology is always related to the community life of the people; how they socialize or how they interact with the whole society. This kind of study is also found in the book Southern Honor. It can be seen that several honors of the Southerners are related to heir life in the community, Therefore, Southern Honor also includes the sociological study. This is relevant to the statement in the book Southern Honor saying that "honor, not conscience shame, not guilt, were the psychological and ocial underpinnings of Southern culture ( $\mathrm{p}$. 22)". Also, it is stated that honor provided a framework for handing social problems (p. 64) One of the important issues in the tatus. Many historical accounts have recorded the great concerns of the Southerners for social status. Because of the slavery system in the South, there are a class consciousnes the book Southern Honor. It is stated that dealing with the relationship between the the honors of the Southerners will greatly slave owners and the slaves themselves, the sociological study is the concern for social 
relationship between the rich and the poor, the relationship between the aristocrats and the non-aristocrats, etc. That is why, socia status or social order in the American South is always given great attention.

Such a concern can be traced on the relation of the honor to social order in the South. According to Brown, there were three factors influencing the social order in the Southern society. They are the nature of rankings in the patriarchal household, the connection of wealth with community power, and the dilemmas implicit in protest and rebellion against the rule of family and government (p. 64).

These aspects can be proved in the American South for during its history, these are several conflicts or rebellions, such as the conflicts between the slaves' owners and the slaves themselves caused by the slavery system, the conflicts between the Southerners and the Quakers, etc. It can also be proved by looking at the social strata in the Southern history. The relationship of the yeoman and the planter in society, the efforts of the Southerners to build and maintain their design by having a dynasty equipped by the possessions of lands, wealth slaves, and a wife. Such a social concern can be seen in the novel of William Faulkner entitled Absalom, Absalom through the character of Thomas Sutpen. Even though Thomas Sutpen is a fictional character, his behavior represents the ways of life of the Southerners, particularly in the Old South. Thus, the ways the Southerners socialize in the society or the ways they interact in their community life give facts about their sociological condition.

Psychology

Psychology is the study on human behavior. The main issues are on the ways to build characters or behaviors. The behaviors of a person will be much influenced by their environment, either in family or in society.

The study of psychology can also be traced in the book Southern Honor. It can be seen that the possession of certain honors gives psychological influences in the Southerners life. Brown stated that honor, not conscience, shame not guilt were the psychological and social underpinnings of Southern culture. ( $p$. 22). For example, the Southerners' tendency to get married based on blood kinship could give psychological stability. Blood kinship through marriage offered the promise of stability, both nancial and psychological. (p. 222).

The psychological aspect of the Southern Honor can be clearly seen in the relationship of the Southerners to their family. The father and mother's relation to children gives psychological contribution parents of high gentility perceived the child as a moral figure to be molded as if made of clay, not as an independent personality with talents, interests, and temperaments to be developed for individualist rather than family needs (p. 132).

Because of this concept, the father and mother in the South try to treat their children properly and wisely. For example, to rise up God-fearing, hard-working, and wellmotivated children, the evangelical Yankee mother sought to channel the young person toward wholly effective self-mastery. While the fathers themselves will try to withhold affection from the wayward child, rather than to react with a boxing of the ears in the hat of the moment (p. 128). Such a treatment will, of course, give psychological impacts on the life of the children including their behavior or character in family or in society.

Another example is the impact of the naming pattern in the American South, which stresses on the male ancestors. According to Brown, by emphasizing male ancestors for the family name, it helped to cement solidarity between grandchildren and grandparents, gave mothers and wives reason for pride as bearers of their fathers' names, and also served as a guide for the son (p. 122). This tendency, bear the psychological relation among the family of the Southerners.
Literature the use of literature. In the American Studies theory the use of literary writing is very important because it can be used as a mental evidence reflecting the real experiences in society. Brown, the writer of the book Southern Honor, uses so many works of literature as a mental evidence to prove the experiences of the Southerners in the Old South.

For example, the novel Absalom, Absalom! Written by William Faulkner is used to explain the tendency of the Southerners to have a dynasty by having land and any other wealth in order to be honored in society. Through the character Thomas Sutpen, Faulkner described the curious relationship between leader and follower in the rural south just after the Civil War (p. 62). Also, in the novel, Intruder in the Dust, Faulkner described that the old, primal sense of honor was still felt in the next generation and no distinction at all. The character, Charles Mallison represented this kind of circumstances, one who was raised to make no distinctions between his forefather in the past and his own life (p. 112).

Other literary works used by Brown as a mental evidence in Southern Honor are the plays of Tennessee Williams, especially The Glass Menagerie, A Streetcar Named Desire, and The Eccentricities of a Nightingale. These plays explore the theme of unavoidable dependency in one proud family in the Southern society (p. 333).

The historical background can not be neglected in Southern Honor. Since the book itself is concerned with one aspect in American society, i.e. the American South, the historical analysis is also included in it. Throughout the book, one finds several events happened in the Southern history, such as the Civil War, slavery system in the Southern history, $\mathrm{Ku}$ Klux Klan, etc. However, such a study is not so emphasized in this book.

The above analysis of Southern Honor prove that this book applies an interdisciplinary approach which becomes the main characteristic of the American Studies discipline.

The Reconciliation of Region, Nation, and World The third characteristic of the American tudies discipline applied in this book is the use of place context: region, nation, and world. According to this theory, the place context in merican Studies moves from the micro to macro things. The explanation should begin rom the region to represent the nation and hen to the world as a whole. It means that in explaining the American experience, Brown, the writer of the book Southern Honor uses a little part of American experience but the one that an represent the whole American experience.

Brown has proved this theory in his explanation. He uses a little aspect in th Southerners experiences but it can represent the whole experience of the Southerners. He just explains the honors, one aspect in American South but this explanation can represent the whole life of the Southerners. Furthermore, by exploring this experience in the Southern society, it can represent the American experience as the American South is a part of American society.

One of the ways used by Brown is the use of a certain person or a family as a figure representing the Southerners' honors. In other words, the honor of the Southerners can be seen by examining the life of a certain family in the Southern society.

For example, the Southerners' tendency to the finding of other professions instead of the plantation can be found in Armand de Rosset's family. Armand de Rosset, a planter and physician of Wilmington, North Carolina boasted in 1847, "My grandfather, my father and myself and both my son have been practitioner of medicine in this place. All of them had been and were plantation owners as well (p. 182)".

Another example is Samuel David Sanders, a man from Georgia who represents the brave conduct of the Southerners. When the Civil Wa egan, he mused about Confederate enlistment, "I would be disgraced if I stayed at home, and 
unworthy of my revolutionary ancestors (p. 35)".

Furthermore, to describe the anatomy of a wife-killing in the Southern society, Brown used an example from one family, the Foster's family. He explained the killing of Susan Foster near Natchez, Mississippi, in March 1834 (p. 462).

The above examples prove that Bertram Wyatt-Brown, the writer of Southern Honor, reflects the American experience in the South in the context of place.

\section{Conclusion}

Based on the above analysis, it can be concluded that Southern Honor is one of the American Studies discipline. This is because the writer of this book, Bertram Wyatt-Brown, applies some theories of American Studies in explaining the basic ideas.

By analyzing this book, it can be found that the theories of American Studies applied are the first is reconciliation of tenses such as: past, present, and future; the second is reconciliation of academic disciplines or interdisciplinary approach such as the use of anthropology, economics, politics, sociology, psychology, literature, and history. Finally, the third is reconciliation of region, nation, and world, or moving from the micro to macro things.

This analysis gives an example of the application of American Studies methods. Also, it proves that works of American Studies discipline are different from works of other disciplines.

The existence of this book signals another advance in American Studies as a discipline. Since the birth of American Studies, there have been so many works produced. This fact proves that American Studies discipline is becoming more important, particularly in relation to the efforts in searching for American experiences. It also proves that American Studies is not merely information about the United States, but also an academic discipline.

\section{References}

Brown, Bertram-Wyatt. (1982). Southern honor: Ethics and behavior in the Old South. New York: Oxford University Press.

McDowell, Tremaine. (1948). American studies. Minnesota: The North Central Publishing Company, St. Paul.

Meredith, Robert. (1968). American Studies: Essays on Theory and Method. Oxford, Ohio: Charles E. Merrill publishing Co.

Wise, Gene. (1975). Paradigm Dramas in American Studies: A Cultural and Institutional History of the Movement. Maryland: University of Maryland. 